\title{
Research on Strategy of Strengthening the Integration of Industry and Education between Private Colleges and Enterprises
}

\author{
Guangliang Zhu \\ Xi'an Peihua University \\ Xi'an, P. R. China
}

\begin{abstract}
As an important part of cultivating socialist constructors and successors, private colleges play a more and more important role in higher education. In order to cultivate the first-class high-quality talents so as to meet the need for social and economic transformation and talents demand-side reform, private colleges must strengthen the integration with the enterprise. This paper points out the significance of cooperation, exchange and integration between private colleges and enterprises, the main content of the integration. The methods of integration are also discussed from three aspects: concept renewal, interest relation and operation mechanism. Some countermeasures are put forward with the purpose to offer some ideas and references for the integration of industry and education and cooperation between colleges and enterprises.
\end{abstract}

Keywords-private colleges; enterprises; integration of industry and education; strategy

\section{INTRODUCTION}

With the development of educational supply-side and demand-side reform, our country is determined to construct applied for technical universities, and more than half of ordinary civil universities will reform to cultivate applied talents [1]. In order to train applied talents suitable for the development of regional economy, private colleges in China must pay close attention to market demands and increase cooperation between schools and enterprises and integration of industry and education. The integration of industry and education is to deepen the cooperation between industry and education, to construct specialties towards industries, to improve the relationship between teaching and industry, to urge colleges to become operational entities with the functions of talent training, scientific research and scientific and technological services. The flexible running mechanism of private colleges is more conducive to promote the integration of industry and education and cultivate applied talents with hard thoughts, excellent quality and first-class professional skills to meet the needs of enterprises. Private colleges and universities can set up relevant enterprises according to their professional needs. Also, they can cooperate deeply with social enterprises. Under the influence of many factors, such as capital, market and so on, it is impossible to set up a corresponding enterprise for every major. Therefore, it is an inevitable way to run a school jointly with social enterprises, to deep integration and school-enterprise cooperation. To meet

This work was financially supported by: Project of China Vocational Education Society of Shaanxi Province in 2019: Research on Present Situation and Countermeasures of Vocational and Technical Education in Shaanxi Province (Grant No. ZJS201901). the needs of enterprises, we must strengthen the in-depth exchange and cooperation between colleges and enterprises. Efforts must be paid to ordered talents training, establishment of a win-win cooperation mechanism between the two colleges and enterprises, so as to realize the sharing of resources, information and personnel, to participate in all aspects of education and teaching, to formulate a talent training scheme, to construct a curriculum system, to create teaching content, to perfect practical practice links, to truly realize complementary advantages, resource sharing, mutual benefit and mutual benefit, and to cultivate applied talents who master technologies, can operate machines, and know management, so as to meet the needs of social development.

\section{A CLEAR UNDERSTANDING OF THE SIGNIFICANCE OF STRENGTHENING INTEGRATION BETWEEN PRIVATE COLLEGES AND ENTERPRISES}

\section{A. Strengthening the integration of industry and education in} private colleges and enterprises is the objective requirement of the theory of supply and demand for education

The cultivation of talents in colleges also follows the theory of market supply and demand. The college is the supply-side, the enterprise is the demand-side. The college, as the educational service supplier, should provide the enterprise with "consumption" according to the enterprise demands. This kind of "consumption" is composed of talents supply and science and technology service [2]. As producers and trainers who serve regional economic development and future industrial needs of applied talents, private colleges must work hard to meet the requirements of supply and demand, train talents to master solid subject knowledge, have a certain working ability, must meet the needs of enterprises and be competent for the posts provided by enterprises. It requires private colleges to respect the realistic and future needs of the enterprises, and so as to develop their students to meet the future post requirements.

\section{B. Strengthening the integration of industry and education in} private colleges and enterprises is the objective requirement of vocational education.

Most private colleges and universities take vocational requirements as the guideline of their vocational education and regard building high-level application-oriented technological colleges and universities as their to development goals. The 
"combination of industry and education and the integration of school and enterprise" is the road to the development and construction of private colleges and universities[3]. The occupational requirement of application-oriented universities requires that the private university should run the school according to the needs of enterprise work lines, so as to realize the seamless connection between the personnel training and enterprise posts demands, which is the inevitable requirement of the mutual construction of vocational education by both the university and the enterprise. This requires the universities and enterprises to train the talents according to the social needs, strengthen their cooperation, and determine the training target according to the actual position demands and future development, and to set up an application-oriented curriculum system. At the same time, to establish a quality evaluation standard suitable for the applied talents, and to construct a "double qualified teachers" faculty are also required, in order to ensure the training of talents with enough knowledge, skills and qualities.

\section{To strengthen the integration of private universities and enterprises is an objective requirement to promote the development of enterprises}

With the development of new industry, new business types and new technology, enterprises need to establish knowledge-rich chains of industry and innovation. The private colleges got some achievements in the transformation of their scientific researches and accumulated certain experiences. Motives of private colleges' development come from the demand of enterprises for talents, while the development of enterprises also needs the scientific and technological and talents to support provided by private colleges. Using their educational resources and employing industry experts, private colleges and universities can provide high-quality training and services for enterprises, and then improve the ability and quality of the existing personnel of enterprises. The private colleges and enterprises can jointly do some key scientific researches and then reply to their research achievements into the industry, so as to improve the productivity level and economic benefit of the enterprise.

D. To strengthen the integration of industry and education in private colleges is the objective need for their survival and development

At present, the pressure of survival and development of private colleges is still very prominent. With the promotion of the aging society in China, the source of students continues to decline. Due to low talents training quality and less social recognition, some private colleges and universities will be eliminated in future competition. In order to build high-level applied colleges, they have to analyze the market demands by study the beginning and development of education. The employment situation of graduates determines the source of students in the future, while the market demand of enterprises determines the development of private education. Strengthening the integration of industry and education can enable students to understand the needs of future posts, and thus deepen their understanding of knowledge. Their abilities to solve practical problems can be improved, and their innovation and entrepreneurship can be stimulated. By strengthening the integration of schools and enterprises, teacher's all-round development can be promoted, conditions and opportunities for teachers to participate in practical work can be provided, and thus the lack of their practical work experience and the problem of less combination between theory and practice can also be resolved. What's more, the scientific research practicability of private colleges can be strengthened, and the transformation of their scientific research achievements can speed up.

\section{COUNTERMEASURES OF STRENGTHENING INTEGRATION OF INDUSTRY AND EDUCATION IN PRIVATE COLLEGES AND ENTERPRISES}

\section{A. Both private colleges and enterprises should speed up the renewal of concepts}

As the spiritual pillar of colleges' development, a school running concept, with functions of guidance, regulation, and stimulation, determines the development of colleges. In order to accelerate the renewal of the school running concept, private colleges must change their quantity-oriented development to quality-oriented development, from their scale-based construction to connotation-based construction. And they must establish a unique school running concept and development direction by learning the advanced experiences of school-enterprise cooperation at home and abroad. As applied technological colleges, private colleges should pay much attention to the development of subject-based culture, the practical application of knowledge, the cultivation of the craftsman spirit, so as to improve their students' skills and practical abilities of organization, management, planning, and coordination. Private colleges should actively serve enterprises and society according to their actual demands and development. They should adjust their talent training programs, curriculum systems and teaching methods based on the research of talents demand information of enterprises and society.

In order to encourage the cooperation between colleges and enterprises and the integration of industry and education, and to improve applied talents training, the central government has issued a series of policies and regulations[4]. At the same time, enterprises should also establish the concept of win-win cooperation; adhere to the accordance of short-term interests and long-term interests, and the accordance of interests of both individual enterprise and the state. The development of enterprise potentials cannot be realized without the cultivation of high-level professional talents. Enterprises must regard human resources construction and science and technology research and application as the core strategy of their construction and development. Therefore, they actively seek support and cooperation with colleges, and take part in scientific researches and the whole process of talent training of colleges and universities. With considerations of needs and development of enterprises, colleges and universities can promote their timely innovation about teaching content, teaching methods, and related mechanisms, in order to further improve the quality of applied talents training.

\section{B. To strengthen the interests of private colleges and enterprises}

For a profit-oriented enterprise, it is necessary to clarify the relevant points of the interests of both itself and the college in 
their cooperation. A private college, whether it is a non-profit school or a profit-making school, has great economic autonomy in a certain degree, and its investment of the funds into the industry, scientific research, integration of industry and education is in line with the national policies. During the course of the cooperation between enterprises and colleges, the related interest points must be clarified and strengthened in order to grasp the key points of the integration of industry and education, and thus the win-win result can be realized. The main purpose of a college in searching for integration with an enterprise is to obtain the enterprise's talents demand information, practice places and scientific research projects, and to hire enterprise's experts, professionals to give lectures or to be part-time teachers in the college. While the main purpose for an enterprise to seek interaction with colleges is to obtain the support of talents, science and technology. Therefore, the related points of interest between the two sides lie in science, technology and talents. Because of the particularity of the private colleges and their school running orientation, the integration of industry and education with enterprises will also form a special interest connecting point, which will become the premise of the integration of industry and education. When private colleges choose cooperative enterprises, they should make scientific cooperation agreements and set up a cooperative community according to the needs of the development of both sides.

The path of interests association in cooperation between private colleges and universities and enterprises should be recognized [5]. On the basis of matchmaking by relevant government departments, talents training and research system should be set up according to college's education and teaching and enterprise's scientific research. The scientific and technological research achievements must be applied in industry, and thus a cooperation approach of "from colleges to enterprises" and "from enterprises to colleges" will be established. The cooperative path takes science and technology and talents as abridge. An enterprise chooses cooperative private colleges and universities mainly according to their tradition, reputation, strengths and other personality characteristics. This requires the private colleges and universities to constantly strengthen their strength, strive to create characteristics, and enhance the strength of scientific research. Only in this way, can the colleges and universities obtain the initiative in the integration of industry and education. At the same time, private colleges and universities should take students as the center, highlight the main position of students, pay attention to the requirements of enterprises for talents in the training link, adjust the training objectives of talents dynamically, set up specialties and courses reasonably, and carry out flexible learning system. Taking talents demands of enterprises and student's ability growth as the core, various resources and system platforms should be established to ensure students' multi-directional learning and practical exercise, and the evaluation and monitoring system of educational service quality should be improved.

The strategy of related interests of both the college and enterprise should be improved in the integration of industry and education. Firstly, private colleges should meet the needs of enterprises for applied talents. The running of private colleges should be closely related to the market demands. The private colleges should accurately establish their training target of applied talents training, and then set up their training programs, disciplines, and curriculum arrangement. During the whole course of talents training, private colleges should try to meet enterprises' needs for applied talents to the greatest extent Secondly, private colleges should actively participate in the personnel training of enterprises. By making fully use of educational and teaching resources, private colleges can actively carry out on-the-job training for enterprises' personnel according to their needs. By this way, the private colleges can close the relationship with enterprises, and get a lot of practical experiences and talents demand information from the enterprise. What's more, by putting the experiences and information into their classroom teaching, the private colleges can settle the problem of their classroom teaching separation from the reality of the enterprise. Thirdly, private colleges should actively provide scientific and technological support for enterprises. In the process of integration of industry and education, private colleges should pay attention to the professional construction and the cultivation of teachers' scientific research ability, the improvement of scientific and technological serviceability.

\section{To perfect the operation mechanism of integration of Industry and education between private colleges and enterprises}

An organization is the guarantee of the cooperation between two sides. It is necessary to establish an organization for the integration of private colleges and enterprises in line with the interests of both sides, in order to ensure the communication and exchange between the personnel of the two sides, and thus to gradually form a stable cooperative relationship. An office for the integration of industry and education should be established, which will be composed by personnel of both sides. This office is responsible for the cooperative research and investigation, and decision-making consultation for private colleges to scientifically formulate talents training schemes, curriculum systems and teaching plans in line with the market needs of enterprises, so as to give full play to the role of enterprises in talent training. The office has the function of supporting research cooperation, and a direct bridge between colleges and enterprises to communicate with each other, which is conducive to the formation of complementary advantages and sharing of knowledge, information resources, and the matching of supply and demands between the two sides. All this can make the teaching, scientific research and personnel training of colleges better serve the needs of economic development.

A practical training base for the cooperation between colleges and enterprises and its role in the integration of industry and education should be fully played, such as carrying out the teaching, practice and research tasks[6]. On the training base, students can directly participate in the work practice, by taking the advantages of enterprises' resources, and thus they can become familiar with the business process of the enterprise and feel their cultures. The training base can also be established by the colleges with the needed practical equipment provided by the enterprise. And the enterprise can send technical personnel to carry out the guidance and offer other 
help in students' practices. The training base will deepen the cooperation relationship between the college and the enterprise, and its other functions in scientific research, teaching, and practices can be fully played. As a result, the base can better promote the effective integration of resources and mutual sharing of information on both sides.

Private colleges should optimize the construction of professional courses and improve their abilities to service enterprises. In order to focus on the pertinence and adaptability of talent training, private colleges must set up a reasonable specialty and curriculum system. Firstly, the disciplines should be designed and set up reasonably. The discipline setting of private colleges should be based on a combination of their own strength of running schools and needs of society, under the guidance of the national professional catalogue. Also, the disciplines should be adjusted in time according to the general principles of specialty setting and the trend of social and economic development. In fact, the private colleges should pay much attention to the trend of economic and social development, and then focus on developing a few disciplines urgently needed by enterprises, and thus to form some disciplines with unique characteristics. Secondly, a scientific and reasonable curriculum system should be established. Based on principles of education and teaching, certain reform and innovation about the content, modes, approaches, and mechanism of teaching should be accelerated. The enterprise experts and skilled workers can be invited to participate in designing and carrying out the teaching content, syllabus, teaching plans and units according to the practical needs of enterprise posts. Base on students' core abilities' cultivation, a better curriculum system can be established by adopting a curriculum establishing mode of combining common skills and specific knowledge, by carrying out a flexible learning system, by increasing the proportion of elective courses, and by optimizing the academic system.

Personnel communication and interaction between colleges and enterprises should be strengthened. A talent exchange mechanism should be set up and improved. The establishment of long-term, stable and institutionalized ties between the personnel of both sides is the guarantee of close cooperative relations. Specific personnel exchange approaches can be adopted, such as the exchange of personnel work posts of both sides, the invitation of enterprise personnel to teach in colleges, the mutual payment by both sides, the invitation of teachers and students to practice in enterprises, and so on. The two sides should formulate a system to guarantee cooperation. Private colleges and universities can take teachers' participation in integration between industry and education into consideration in teacher's evaluation, such as the identification of double qualified teachers, the promotion of professional tiles, performance evaluation. Thus teachers can be encouraged to go to the enterprises to get more deep knowledge of the industry, and then to improve their practical research and teaching abilities. While a flexible learning system can encourage students to go to enterprises to practice. On the other hand, enterprises should establish corresponding rules and systems to encourage their staff to actively take part in the integration between industry and education. For example, the experienced workers can go to colleges to teach, and the general staff can go to colleges to study and improve themselves.

\section{CONCLUSION}

In order to promote the important way to the improvement of applied talents training quality, special corresponding institutional regulations and mechanisms about integration between industry and education have been established at the national level. Both colleges and enterprises must actively search for the starting point of cooperation, establish a long-term cooperation mechanism, and carry out school-enterprise cooperation. As applied technical higher education institutes, private colleges and universities should give full play to their own flexible advantages of school running, renew their ideas and concepts, perfect their institutional mechanisms, encourage teachers to participate in the integration of industry and education, formulate talents training objectives in line with regional economic development, and construct a curriculum system suitable for students' development, scientifically carry out their education and teaching, and finally improve talents training quality. Enterprises should give full play to their own market advantages and make good use of the intellectual and technical advantages of private colleges and universities. In order to realize the win-win result of the integration between industry and education, enterprises should actively look for their common interest points and offer enough support to talent cultivation. With the national policy support and the joint efforts of schools and enterprises, the integration of industry and education will be of great help for the improvement of applied talents training quality.

\section{REFERENCES}

[1] http://www.moe.gov.cn/srcsite/A03/moe_1892/moe_630/201511/t20151 113_218942.html

[2] Xing Yue. Analysis on the Knowledge Map of Education Supply Research in China [J].The Theory and Practice of Innovation and Entrepreneurship, 2019, 2(11):85-86.

[3] Kong Xiangrong, Lin Xiaolan. Research on the Construction of Talent Cultivation System of Innovation and Entrepreneurship Education in Private Colleges and Universities based on the Integration of Industry and Education) [J]. Pioneering With Science \& Technology Monthly, 2019, 32(7):127-129.

[4] Zhu Huijuan, Cong Yuhua. Analysis and Study on Path of Deepening the Integration of Industry and Education in Private Universities[J].The Theory and Practice of Innovation And Entrepreneurship, 2019, 2(2)137-138.

[5] Tan Yi, Hu Zhengrong, Tang Quan. A probe into the internationalization of Talent training in Private Colleges and Universities[J]. Journal of Guangxi Open University, 2018, 29(5):57-61.

[6] Qi Yali. Construction and Management of training Base in higher Vocational Colleges based on Innovation and Entrepreneurship Education[J].Education and Vocation, 2019, (16):84-87. 